\title{
The development of a factor based instrument to measure corporate entrepreneurship: A South African perspective
}

\author{
C.J. Goosen, T.J. de Coning and E.v.d.M. Smit* \\ Graduate School of Business, University of Stellenbosch, \\ PO Box 610, Bellville 7535, Republic of South Africa \\ evdms@usb.sun.ac.za
}

Received June 2002

\begin{abstract}
This article outlines a conceptual model of corporate entrepreneurship in which management's influence on an organisation is highlighted. The model is intended to depict the organisational elements that relate to South African industrial organisations. Corporate entrepreneurship or intrapreneurship is represented by a set of three 'key factors'. Two key factors were taken from the well researched ENTRESCALE (Knight, 1997) and focus externally. The other key factor focuses internally and represents management's influence on structures and processes, and relations.
\end{abstract}

\begin{abstract}
The model encompasses product lines and changes, research and development leadership, new techniques employed in the organisation, the organisation's competitive posture and its risk-taking propensity, its environmental boldness and the decision-making style of management in terms of external opportunities. The model also addresses internal structures and processes, as well as relations. It emphasises intrapreneurial goal setting, and promotes the use of a system that facilitates and manages creativity and innovation. It addresses an intracapital system to supply resources and it facilitates communication. The model allows for staff input to management, a degree of intrapreneurial freedom, a problem-solving culture and empowered staff. Finally, it provides for the championing of intrapreneurship by management.
\end{abstract}

The model is tested in context. There is significant negative correlation between intrapreneurship and organisational age, but not between the intrapreneurship and organisation size. The intrapreneurship factors furthermore correlate significantly with the measure of share price volatility, $\beta$ (Beta).

*To whom all correspondence should be addressed.

\section{Objective and review of intrapreneurial factors}

The main objective of this study was to identify key factors that will augment to the 'classical' intrapreneurship model and thus aid in the understanding of corporate entrepreneurship. A second objective was to investigate the relationships between the contextual variables age, size and riskiness and the key factors dimensions of intrapreneurship.

Common intrapreneurial elements identified in the review of literature are briefly listed below. These elements, and the authors that subscribe to them, are summarised in Table 1.

\section{Background to instrument}

Previous views of intrapreneurship resulted in what can be described as a 'classical' model for intrapreneurship. This model contains the main elements innovativeness, selfrenewal and proactiveness. Some authors (Antoncic \& Hisrich 2001) add the dimension 'new business venturing'. For the purposes of this study, this specific dimension was seen as a salient characteristic because it can result in new business creation within an existing organisation. It was not taken into account directly, however, but rather indirectly, as it is regarded as a result of intrapreneurship and is not necessarily part of the intrapreneurial construct.
Table 1: Elements of intrapreneurship

\begin{tabular}{ll}
\hline Element & Description \\
\hline $\begin{array}{l}\text { Entrepreneurial } \\
\text { teams }\end{array}$ & $\begin{array}{l}\text { Intrapreneurship is practised in a team } \\
\text { environment. }\end{array}$ \\
\hline $\begin{array}{l}\text { Freedom and } \\
\text { empowerment }\end{array}$ & $\begin{array}{l}\text { Entrepreneurial teams are empowered. A } \\
\text { measure of freedom exists. }\end{array}$ \\
\hline $\begin{array}{l}\text { Executive } \\
\text { champions }\end{array}$ & $\begin{array}{l}\text { Top management must champion and support } \\
\text { intrapreneurs. }\end{array}$ \\
\hline $\begin{array}{l}\text { Trust and } \\
\text { management style }\end{array}$ & $\begin{array}{l}\text { Intrapreneurs must be trusted in a non- } \\
\text { penalising environment. Management styles } \\
\text { should promote intrapreneurship. }\end{array}$ \\
\hline $\begin{array}{l}\text { Communications } \\
\text { and feedback }\end{array}$ & $\begin{array}{l}\text { Feedback should be given constantly. Sharing } \\
\text { of ideas should be promoted. }\end{array}$ \\
\hline $\begin{array}{l}\text { Rewards and } \\
\text { recognition }\end{array}$ & $\begin{array}{l}\text { Intrapreneurs and their work should be } \\
\text { recognised. Results should be rewarded. }\end{array}$ \\
\hline Sharing & Resources should be shared. \\
\hline $\begin{array}{l}\text { Creativity and } \\
\text { innovation }\end{array}$ & $\begin{array}{l}\text { Creativity and innovation should be } \\
\text { promoted. }\end{array}$ \\
\hline Intracapital & A system of intracapital should be installed. \\
\hline 'New blood' & $\begin{array}{l}\text { 'New blood' introduces new ideas into } \\
\text { organisations. }\end{array}$ \\
\hline Success promoted & $\begin{array}{l}\text { A positive environment should be created } \\
\text { through the promotion of successes. }\end{array}$ \\
\hline
\end{tabular}

Sources: Adapted from Kurato, Montago, Naffziger, \& Hornsby, (1993: 30); Pinchot (1989: 242); Pryor \& Shays (1993: 44); Fry (1987: 4); Ducan, Ginter, Rucks \& Jacobs (1988: 16); Brazeal (1996: 64); Sathe (1989: 24); Gardiner \& Whiting (1997: 44); Stevenson \& Jarillo (1990:23). 
The innovativeness dimension of the classical model refers to products and service innovation, with the emphasis on development and innovation in technology. Intrapreneurship includes new product development, product improvements and new production methods and procedures. Morris and Sexton (1996: 6) describe this dimension as the seeking of creative, unusual, or novel solutions to problems and needs. The self-renewal dimension indicates the transformation and changes of organisations through the change of key philosophies. It also points to learning or adaptation as dictated by the organisational environment (Zahra, 1991; Guth \& Ginsberg, 1990; Stopford \& Baden-Fuller, 1994). The third dimension, proactiveness, describes the organisation's posture in relation to its competitors

These three dimensions integrate the various views of the intrapreneurship construct but do not adequately describe the effect of an organisation's management on intrapreneurship, especially in terms of its employees and processes. Only the dimension representing self-renewal points to some extent to the influence of management on internal processes. The focus of entrepreneurial dimensions tested with various instruments (ENTRESCALE (Covin \& Slevin, 1989); entrepreneurial intensity (Morris \& Sexton:
1996); KEYS (Amabile et al., 1996); entrepreneurial attitude orientation (Robinson, Stimpson, Huefner \& Hunt, 1991); entrepreneurial quotient by Caspari (1985) to name a few) is either the entrepreneur, a specific dimension of intrapreneurship or the instrument focuses outwards with little exploration of the internal environment, processes and structures and management's effect on them.

This study attempted to rectify the concern described above. It should be viewed within the integrative framework for intrapreneurship developed by Morris and Kurato (2001) as an addition to the area 'organisational context.'

\section{The research relationships}

The research relationships are illustrated in Figure 1

In this model $\mathrm{Y}(\mathrm{I})$ represents the level of intrapreneurship and $\mathrm{O}_{i}$, and $\mathrm{P}_{\mathrm{i}}$, the classical dimensions, while $\mathrm{C}_{\mathrm{i}}, \mathrm{S}_{\mathrm{i}}, \mathrm{T}_{\mathrm{i}}, \mathrm{M}_{\mathrm{i}}$, $\mathrm{E}_{\mathrm{i}}, \mathrm{R}_{\mathrm{i}}$ and $\mathrm{I}_{\mathrm{i}}$, (all new dimensions) are all variables distilled from the literature to augment the classical intrapreneurship model.

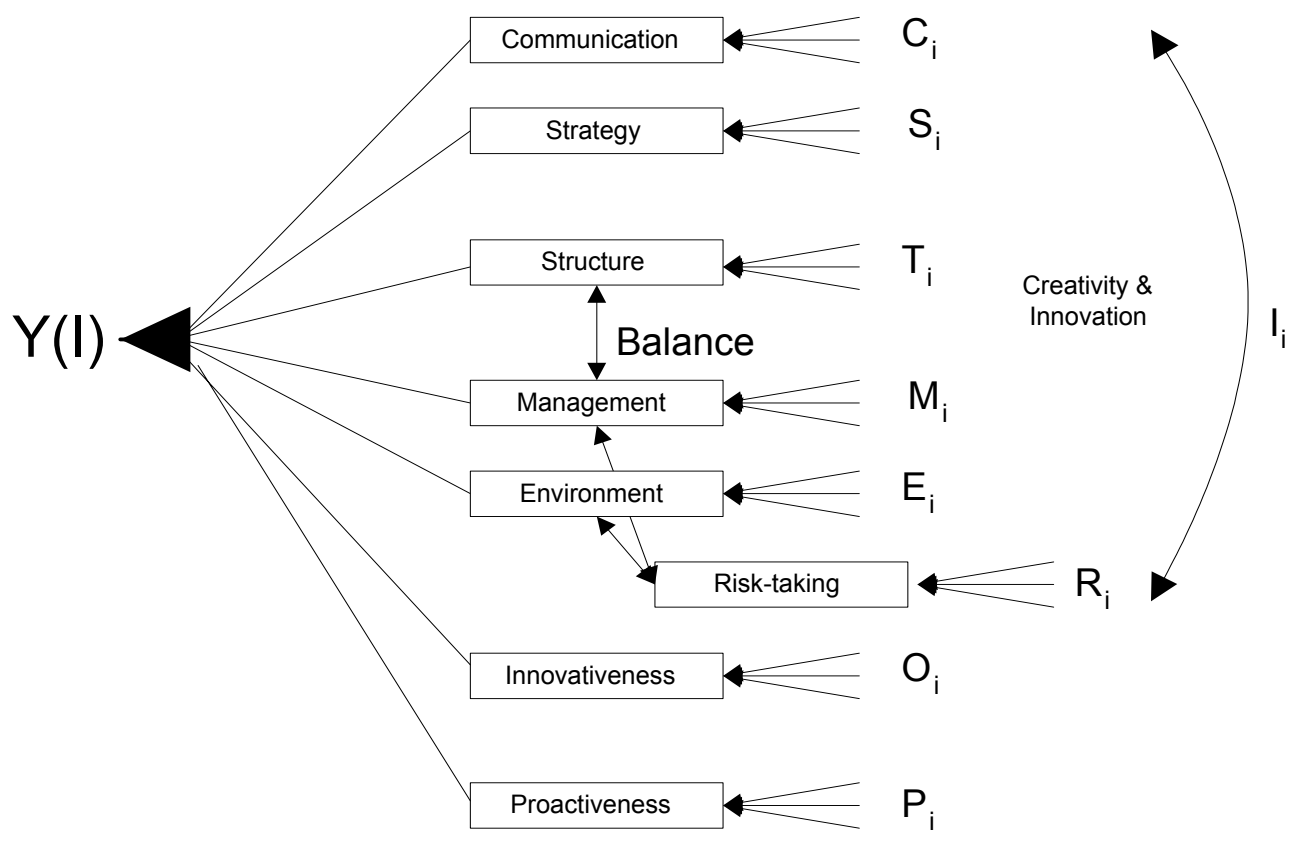

Figure 1: The research relationships

The dimensions and their items used in the study are briefly summarised below.

Management style and orientation: Need for control; innovation experience; goal setting; democratic style; people focus; risk averseness; long-term focus; executive championing of Intrapreneurship; support for intrapreneurship; culture driver of innovation; open communicator; corporate vision for intrapreneurship; trust; allow input from below; encouragement; future orientation; manage entrepreneurial problems (e.g. planning fallacy); develop skills; structures; limit over-control; culture of empowerment; don't use traditional controls; envisioning/inspiring; discretionary powers to intrapreneurs.

Communication: Open communication: no 'turf' in communication; synergism; no hierarchical communication; operational feedback; information exchange; share ideas.

Environment: Scanning processes; learning culture; no risk averseness; no defined 'turfs'; intrapreneurial freedom; empowered employees; serendipity practised and encouraged; rewards and recognition; access to resources; changes recognised as opportunities; problem-solving 
culture; excitement; experimenting culture; internal environment conducive; idea-receptive environment; freedom and empowerment; opportunities part of culture; creative climate; interactive learning.

Structures: Informal, flat structures; teams for intrapreneurship; intracapital; generic structures; structure should support intrapreneur; integration of sub-systems.

Strategy: Systematic planning for intrapreneurship; specific strategies; goal support for intrapreneurship; seeks new ventures; adaptation; long-term focus; administration strategy for resources; venture model in strategy; couple rewards to strategies; employ intrapreneurship as strategy.

Risk-taking: Support; structure; resources; trust; changes; tolerance of failure.

Creativity and innovation: System for development, support; practical search for creativity and innovation; prudent assessment of creativity and innovation; serendipity system; managing innovation; process model; promotion plan; streamline to be progressive, focused.

Product innovativeness: Product lines; product changes; R\&D leadership.

Proactiveness: New techniques; competitive posture; risktaking propensity; environmental boldness; decision-making style.

To examine the model in context, the following hypothesis was set for testing:

There is no relationship between the components of the intrapreneurship model and organisational age; employee count; annual turnover; Beta coefficient and employee productivity.

\section{Questionnaire construction}

In order to test the hypotheses, it was necessary to establish and assess the following: the ability of the work environment of the organisations to foster intrapreneurship and, the ability to positively influence creative and innovative behaviour. Respondents' entrepreneurial behaviour had to be ascertained. Management control and the degree of entrepreneurial freedom had to be determined.

The questionnaire was designed by taking relevant sections from the work of various authors.

Innovation and creativity was taken from Amabile et al., (1996) and Mohamed and Rickards (1996). Entrepreneurial spirit was based on the Entrepreneurial Attitude Orientation (EAO) instrument of Robinson et al., (1991). Culture, environment and productivity were taken from Faul (1986). Shared principles of success questionnaire by Gardiner and Whiting (1997) assisted with the business environment, the ability of an organisation to adapt, individual learning and self-development, and empowerment. This resulted in a preliminary questionnaire with 160 items.

\section{Pilot and initial studies}

The original 160 items created in the item pool were tested on a small convenience sample to determine the face validity, ease of reading, presentation and approximate speed of completion of the questionnaire. Based on this information it was decided to trim the pilot questionnaire to 135 items that would take approximately 30 minutes to complete. This conformed to the requirement of the pilot questionnaire to contain 1.5 times the questions intended for the final questionnaire (Smit, 1991: 155). Trimming was done by choosing between questions that would best represent the dimensions underlying each construct and that would thus have face and content validity.

The resulting questionnaire was then tested on a convenience sample, similar to the final population. Questionnaires were distributed to two organisational levels, that of executive and middle management. One hundred and sixty-six useful completed questionnaires, representing five organisations, were returned. This result was subjected to reliability and validity analysis.

The 135 item initial questionnaire yielded a coefficient alpha of 0,9750 . Although of acceptable level, the high alpha indicates that the 135 items are all highly correlated. This problem was addressed during the statistical analysis of the data.

The construct validity of the instrument was determined next.

Tabachnick and Fidell (1996: 640) recommend that at least 300 responses should be used in an attempt to factor analyse data. The initial study yielded only 166 responses that pointed to a potential problem.

The data were subjected to preliminary structural equation modelling, which resulted in an inadmissible solution. Pallant (2001: 152), however, suggests that responses of less than 300 could still result in an acceptable factor analysis if only a few factors underlie the data, and item/scale correlations are high. It was therefore decided that the primary strategy to overcome this problem would be to scrutinise the item analysis done as described by Rubin (1983: 93) and Nunnally (1978: 605) to highlight problemitems. The resulting deletion of items would reduce items and thus improve the probability of a valid model. The item analysis highlighted a number of problem items, and 23 items with negative or very small item/scale correlations were deleted. Unfortunately, this exercise also did not result in an acceptable ratio of responses to items. As a second strategy, it was decided that the suggestion of Pallant (2001: 152) would be followed and only items with high item/scale correlation would be selected. The theoretical structure had to be kept intact, which meant that high item/scale correlation could not be used as selection criterion alone. The following algorithm was therefore used:

- $\quad$ Reject items with item/scale correlations less than 0,5.

- Ensure that the hypothesised dimensions are represented adequately. 
- Within each dimension, choose the item with highest item/scale correlation.

This exercise resulted in an item bank of 64 questions that adequately represented the additions to the intrapreneurship model through seven dimensions namely: Management, Communication, Environment, Structures, Strategy, Risk and Innovation. Cronbach's Alpha calculated for the 64 items is 0,9761 , which point to acceptable reliability but again highlights high inter-item correlations. The individual Alphas are listed below in Table 2

\section{Table 2: Cronbach's Alpha for the dimensions}

\begin{tabular}{ll}
\hline Dimension & Alpha \\
\hline Management & 0,9361 \\
\hline Communication & 0,8282 \\
\hline Environment & 0,9083 \\
\hline Structures & 0,7857 \\
\hline Strategy & 0,8591 \\
\hline Risk & 0,7476 \\
\hline Innovation & 0,8113 \\
\hline
\end{tabular}

Nunnally's (1978) rule of thumb for the inclusion of a dimension is a minimum Alpha of 0,7. As such all the dimensions were retained for further factor analysis.

Factor analysis was then performed on the 64 items that constitute the seven dimensions. Barlett's test of sphericity is significant in that it indicates that there are significant relationships among the items. The Kaiser-Meyer-Olkin measure of sampling adequacy is 0,657 , which confirmed the suitability of the data for factor analysis.

\section{Entrescale questionnaire}

Khandwalla (1977), in an organisational effectiveness study, developed a popular questionnaire to measure various organisational dimensions that are applicable to intrapreneurship. This questionnaire was refined by Miller and Friesen (1983) and Covin and Slevin (1989). It was tested in various studies, including a study for cross-cultural reliability by Knight (1997) and Antoncic and Hisrich (2001). Although various authors have developed similar scales, for example the Corporate Entrepreneurship Scale by Zahra (1993b), or additional elements like the frequency and intensity of entrepreneurship (Morris \& Sexton, 1996: 6), the basic measurement of the refined ENTRESCALE was not altered. Knight (1997) states the goal of the instrument as 'entrepreneurship at the firm level... reflecting the innovative and proactive disposition of management'. The ENTRESCALE includes intrapreneurial orientation as seen in R\&D activities, leadership and proactiveness. It also explores activities such as the number of marketed new lines of products and services. It therefore not only assesses management's orientation (external posture) towards intrapreneurship, but also what management favours and how they act, especially in terms of the external environment and the competition. What it does not address adequately, is the internal orientation towards intrapreneurship.
Utilising the ENTRESCALE to test the described dimensions, and new items to explore the internal orientation can provide additional richness to existing instruments that measure the construct of intrapreneurship.

Knight's (1997: 218) analysis of the test results of the ENTRESCALE resulted in two factors emerging. The first, Innovativeness, is represented by Product lines, Product changes and R\&D leadership. The second, Proactiveness, is represented by New techniques, Competitive posture, Risktaking propensity, Environmental boldness and Decisionmaking style.

In the factor analysis, only one factor emerged. It has a bearing on the influence of management on structures and processes, and on the relationship between management and employees.

\section{Table 3: Rotated matrix}

\begin{tabular}{lc}
\hline Dimension & Factor $\mathbf{1}$ \\
\hline Empowerment & 0,752 \\
CE Championing & 0,739 \\
Staff input & 0,708 \\
CE Goal setting & 0,704 \\
Communication & 0,672 \\
CE freedom & 0,646 \\
Innovation and creativity systems & 0,608 \\
Intracapital & 0,588 \\
Rewards & 0,541 \\
Problem solving culture & 0,520 \\
\hline
\end{tabular}

The factor was named Management, and represents the following ten dimensions:

Goals: This is the inclusion of intrapreneurship in the setting of goals. Goal-orientated pressure can be linked to productivity (Faul, 1986) and should therefore be part of management's dealing with staff. However, intrapreneurship goals should be included during the process of personal goal setting.

Rewards and creativity and innovation systems: Systems and structures that promote creativity and innovations will greatly enhance intrapreneurship. Elements of these systems include a reward system, which rewards intrapreneurial behaviour. It also includes methods through which the creativity is enhanced and through which the different stages of innovation are managed (from conception to final product).

Intracapital: This is a method where a specific portion of expenditure (capital or operational) is allocated beforehand to allow for intrapreneurial actions. Intrapreneurial actions include new ventures, new projects or new methods.

Communication: Open, frank communication without territoriality enhances the exchange of ideas and 
information. It improves productivity and facilitates synergism.

Intrapreneurship championing: Management should be the key driver of intrapreneurial processes in an organisation.

Staff input: This dimension represents areas of the management style in the organisation. It points to democracy where input is received from everyone. By taking cognisance of the views and experiences of staff below, management can expedite many organisational events and processes.

Intrapreneurial freedom: This dimension points to limiting over-control by management and to innovative methods of management rather than the use of traditional controls. It also points to trust and empowerment, and the management of risk.

Problem solving culture: Faul (1986) in his research on productivity identified a problem solving culture as a key element of productivity. This dimension is included in the intrapreneurship construct as an organisation wide approach to work.

Staff empowered: This dimension stresses the management philosophy in which staff can give input, are trusted, and in which staff feel part of creativity processes in the organization. It is essential to unlock personal knowledge and capability to its fullest extent.

Based on this the model was finalised. It is illustrated below in Figure 2

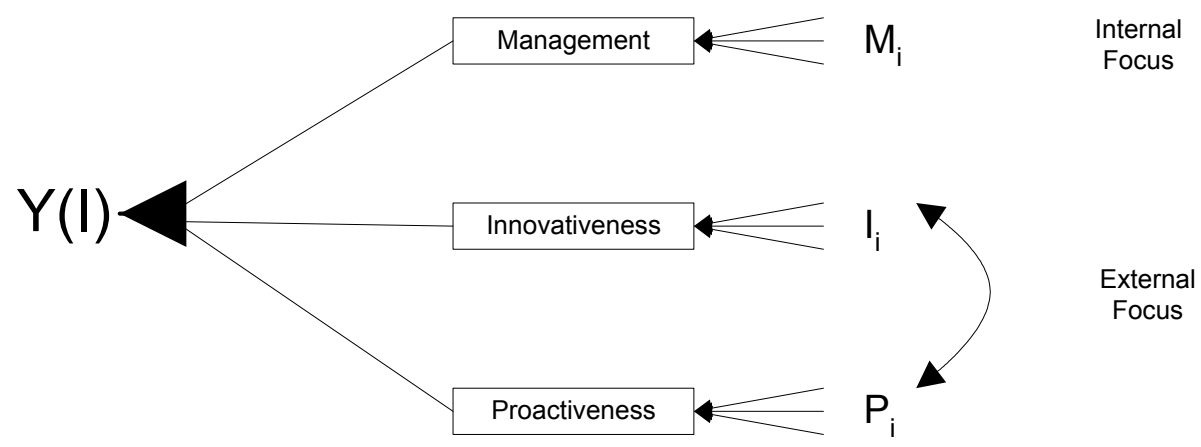

Figure 2: The final intrapreneurship model

Using the methodology described above, a final questionnaire with acceptable levels of reliability and validity was constructed (Appendix A). This questionnaire represents the proposed intrapreneurship model consisting of the three key factors and their associated dimensions.

\section{Organisations included in the study}

Details were available for 231 organisations. A further 12 organisations that operated outside of South Africa, were delisted or were suspended from the Johannesburg Stock Exchange at the time of measurement. These were eliminated from the study. The final population for the study thus consisted of 219 organisations. They were invited to participate in the study. An e-mail message was sent to the Group Human Resource Director of each organisation in November 2001. This message introduced the study and invited participation from an executive member of staff. This was followed up with a formal letter in January. Initial responses by electronic mail were received within 48 hours (approximately $50 \%$ of the final yield). Third and fourth follow-up letters were sent to the organisations. This assured a final result of 109 organisations.

Once responses to the questionnaires were received, the researcher inspected them for usefulness. The inspection procedure resulted in the rejection of 19 responses.

The edited questionnaires were then coded for use in the statistical package SPSS. During the coding process, additional information for each organisation was added. This information was obtained from the Bureau for Financial Analysis (2002). Categories are listed below:

- $\quad$ Organisation age (as at year-end 2000)

- Number of employees

- Employee turnover for the year 2000

- Calculated Beta $(\beta)$ for 3 years

Organisational age was added because it can be reasoned that older organisations are more set in their methodologies, 
are less likely to adapt and that they therefore could be less intrapreneurial.

The number of employees, as well as the annual turnover, were added to establish the relative size of an organisation. Similar to organisational age, it can be speculated that larger organisations tend to be less intrapreneurial, or that an organisation can only be dynamic and intrapreneurial if it is relatively small.

Entrepreneurship and intrapreneurship are akin to risk. The only published measure of risk is the Beta coefficient or measure of market price volatility. Because 'risk' features prominently in the study, it was decided to add the data pertaining to risk.

\section{Statistical tests and data analysis}

\section{Hypothesis -intrapreneurship in context}

In terms of this hypothesis, the relationship between the intrapreneurship factors and the structural variables turnover, age, employee count, Beta and employee productivity was set.

\section{Organisational age}

Organisations of various ages were part of the study. In can be postulated that organisations lose their dynamism as they become older. Similarly organisations could become more rigid and set in their ways and as such could be less intrapreneurial. This sub-hypothesis tests the relationship between the intrapreneurship factors and organisational age. Organisational age was calculated as the difference between the date of inception and the year 2000. The hypothesis was set as follows:

H1: There is no relationship between the intrapreneurship factors and organisational age.

\section{Organisation size}

As is the case with organisational age, the size of an organisation could have a bearing on the level of intrapreneurship. It can be hypothesized that as organisations become larger, they may be less intrapreneurial. Organisation size is determined by two factors, annual turnover and employee count. The year 2000 was used as base during the calculations. The subhypotheses to test this was set as:

$\mathrm{H} 2$ There is no relationship between the intrapreneurship factors and organisational size measured by employee count.

H3 There is no relationship between the intrapreneurship factors and organisational age as measured by annual turnover.

\section{Perceived risk}

There is a popular association of entrepreneurs with risk. Risk is measured within the model, especially in terms of management's attitude towards risk, both internally and externally. However, the risk attached to a specific organisation (as external perception) is not explored. It is beyond the scope of this study to explore risk and its various components in totality, it is, however, possible to touch briefly on the relative risk of organisations.

Investors' reaction (as a group) to their perception of risk is displayed through the volatility of shares (Weston \& Brigham, 1981: 542). Their perception includes the risk attached to a specific share when being compared to the market as a whole.

In this hypothesis, the relationship between risk, as defined above, and intrapreneurship was explored.

The perceived risk profiles of organisations were measured through the calculated $\beta$, in terms of the Capital Asset Pricing Model (CAPM) (Profile: 2000). This is an expression of the sensitivity of the return for a specific share relative to the market as a whole. It can be expressed as follows:

$\beta_{\mathrm{i}} \approx \frac{\mathrm{R}_{\mathrm{i}}-\mathrm{R}_{\mathrm{f}}}{\mathrm{R}_{\mathrm{m}}-\mathrm{R}_{\mathrm{f}}}$

where

$\beta_{i}=$ the coefficient of the $i$-th share, $R_{i}$ its return, $R_{m}$ the market return and $R_{f}$ the return from a risk free investment.

The hypothesis is set as follows:

H4 There is no relationship between the intrapreneurship factors and an organisation's perceived risk.

\section{Testing the hypotheses}

Normality tests indicated that the data were not suitable for parametric testing. The non-parametric Spearman's rankorder correlation coefficient testing was therefore used to test the hypotheses. The results of the tests are listed in Table 4.

Table 4:Spearman's rank-order correlation coefficients indicating the relationship between the intrapreneurship key factors and contextual variables $(\mathrm{N}=86)$

\begin{tabular}{|c|c|c|c|c|c|c|}
\hline & \multicolumn{2}{|c|}{ Innovativeness } & \multicolumn{2}{|c|}{ Proactiveness } & \multicolumn{2}{|c|}{ Management } \\
\hline & $r$ & Sig. & $r$ & Sig. & $r$ & Sig. \\
\hline Age & $-0,102$ & 0,352 & $-0,251^{*}$ & 0,020 & $-0,180$ & 0,098 \\
\hline Turnover & 0,175 & 0,106 & 0,041 & 0,710 & 0,059 & 0,592 \\
\hline Employees & 0,137 & 0,208 & $-0,122$ & 0,265 & 0,082 & 0,451 \\
\hline Beta & 0,103 & 0,347 & $0,275^{*}$ & 0,010 & $0,323 *$ & 0,002 \\
\hline
\end{tabular}

* indicates significant correlation

The results of the hypotheses testing are:

\section{Null hypotheses accepted}

H2 and H3: There is no relation between the intrapreneurship factors and organisational size. 


\section{Null hypotheses rejected}

H1 and H4: There is a relationship between the intrapreneurship factors and organisational age as well as an organisation's Beta.

\section{Conclusion}

\section{Main research model}

In the conceptual of the research, an intrapreneurship model, consisting of the key factors Communication, Strategy, Structure, Management's influence, Environment, Risktaking, Innovativeness and Proactiveness was anticipated. The final model (depicted in Figure 2) that materialised consisted of only three key factors or primary building blocks, namely, Proactiveness, Innovativeness and Management. Two key factors primarily represent an outward posture and one an inward posture. The two key factors projecting outwards, Innovativeness and Proactiveness, were taken from the well-researched work of Khandwallla (1977), Knight (1997), Miller and Friesen (1983), Covin and Slevin (1989) and Antoncic and Hisrich (2001). These two factors encompass changes to product lines, changes to products, $R \& D$ leadership, new techniques, the organisation's competitive posture, risk-taking propensity, environmental boldness and the decision-making style relating to competition.

The third key factor, Management, is the contribution of this study, and it represents management's influence on intrapreneurship internally, especially in terms of structures and processes, and internal relations. This key factor represents an enrichment that can be added to any of the popular models of intrapreneurship.

The key factor Management represents ten dimensions of intrapreneurship namely goals, creativity and innovation systems, rewards, intracapital and communication, staff input, intrapreneurial freedom, a problem solving culture, intrapreneurship championing and staff empowerment.

\section{Age}

The results of the statistical analysis that tested these hypotheses established that significant negative correlation exists between an organisation's proactiveness and age but not between age and the organisation's innovativeness.

It was expected that the first key factor, Innovativeness would have negative correlation with organisational age as organisations become less innovative at the later stages of organisational evolution. This expectation is confirmed by the views of Chandler (1962), Mintzberg and Waters (1982), and Adizes (1988) on the matter. The findings, however, indicated a lack of significant correlation, especially significant negative correlation in which older organisations would show less entrepreneurial behaviour. This could possibly be explained by taking cognisance of the type of intrapreneurship (and specifically the innovation element thereof) examined and by contextualising it.
As a first point of departure it should be noted that although there was only significant negative correlation between the key factor proactiveness and organisational age, there was also negative, (but non-significant) correlation between the key factors innovativeness and management, and organisational age - which confirms the expected direction of the relationship. The fact that the correlation was not significant implies that some of the older organisations are less innovative and less orientated towards intrapreneurship in respect of its management's behaviour, but others not.

The reason for this apparently dichotomous result could possibly lie in the fact that the type of innovativeness examined in the study, is generic in nature. The study did not compensate for the variations produced by the wide range of entrepreneurial characteristics and new venture phenomena, which come into effect in these instances. Gartner et al. (1989: 47), confirms this by suggesting that there are not 'average' situations during venturing. The study also did not account for the specific stage of the growth cycle in which ventures within corporation found themselves, which could have influenced the result.

Cognisance must furthermore be taken of the fact that the corporate level intrapreneurship measurement of the study did not take the effects of entrepreneurship on a subsidiary level into account. Birkinshaw (1999), and Doz and Prahalad (1981) stress the fact that a number of differences can be found in subsidiary entrepreneurship compared to corporate intrapreneurship. Greater levels of autonomy of subsidiaries for example, could have profound effects on entrepreneurship. The lack of significant correlation of both innovativeness and management allude to this. It could also be possible that in some organisations there are greater autonomy of decision making for subsidiaries whereas in others there are not. Furthermore, it could be possible that in some organisations there are levels of autonomy which allow proactive behaviour but which restrict the capital required for innovation in venturing. Zahra, Dharwadkar and George (2000: 22) confirm this possibility in that they found negative, but not statistically significant correlations between subsidiary entrepreneurship and age in a study that examined subsidiary entrepreneurship.

\section{Size}

The statistical analysis found that there was no significant correlation between the key factors and organisation size, represented by turnover or employee count. This unexpected result necessitates further analysis and discussion.

As a first step, it was decided to examine the relationship between organisational size and intrapreneurship using a different measure for size. A number of authors that researched intrapreneurship determined organisational size with measures other than number of employees and turnover for example number and size of subsidiaries (Engelhoff, 1984) or assets (Mansfield, 1963). The asset base of each organisation is known and the relationship between organisational size, as measured by its assets as at the year 2000, and the intrapreneurship key factors was therefore examined. 
Normality tests indicated that the data were not suitable for parametric testing. The non-parametric Spearman's rankorder correlation coefficient testing was therefore used to test the hypothesis. The results of the tests are listed in Table 5 .

Table 5:Spearman's rank-order correlation coefficients indicating the relationship between the intrapreneurship key factors and size (measured by assets $)(\mathrm{N}=86)$

\begin{tabular}{l|ll|ll|ll}
\hline & \multicolumn{2}{|c|}{ Innovativeness } & \multicolumn{2}{|c|}{ Proactiveness } & \multicolumn{2}{c}{ Management } \\
\hline & $r$ & Sig. & $R$ & Sig. & $r$ & Sig. \\
\hline Size & .138 & .202 & .080 & .466 & .104 & .341 \\
\hline
\end{tabular}

The results again confirmed that there is not a significant relationship between organisational size and the key factors. As second step the literature was re-examined for anomalies in respect of research findings about intrapreneurship and organisational age.

The literature is indicative of varied opinions in respect of the relationship between organisational size and intrapreneurship. Aldrich and Auster (1986), Jones and Butler (1992), Ettie (1983) and Dougherty (1990) indicate that larger size could be a liability to intrapreneurship in organisations, because of the sheer number of employees, infrastructure and equity, that could cause organisations to be less flexible in responding to opportunities. Small organisations may also be more flexible in respect of adjusting research plans or in the implementation of innovations. Small organisations may also be more flexible in their compensation policy, specifically in rewarding innovative effort.

Opposed to this is the view that larger organisational size is linked to higher levels of intrapreneurship (specifically innovation). The foundation of this view can be found in the Schumpeterian hypothesis. Schumpeter argues that economic growth occurs through the process of 'creative destruction' in which the old industrial structure, its product, process or its organisational form, is continually changed by 'new' innovative industrial activity. According to Schumpeter, large organisation size is essential to such innovative activity, which he views as being entrepreneurial. (Jennings, 1996:1). Schumpeter argues that larger organisations provide economies of scale, which makes sufficient resources available for innovation. This view is shared by Romanelli (1987), Zahra (1993a) and Bloodgood, Sapienza and Almeida (1995) who believe that organisational size can be indicative of the organisation's resource base, which could facilitate intrapreneurship. Larger organisations could have stronger cash flows to fund innovation. Larger turnovers also implies that the costs of innovations could be spread over the larger sales base. This view is supported by Galbraith (1982) who believes that larger organisational size favours innovation because of the sheer cost of innovation. Larger organisations may furthermore have access to a wider range of human capital skills than small organisations. This in turn would allow higher rates of innovation. From the above in can be proposed that the relative strengths of large organisations are predominantly material. Nooteboom (1994: 327) confirms this by stating that the strengths of large organisations lie in economies of scale and scope, more and cheaper financial resources, possibilities of risk spreading, and greater capacity for specialisation, in people as well as equipment.

However, Jennings (1996: 1) points out that a number of authors believe that the stressing of entrepreneurial activity of large organisations is unfounded (Kamine \& Schwartz (1975), Mansfield (1963), Scherer (1965), and Tushman and Nelson (1990)). He furthermore stresses that Kamine and Schwartz's (1975) review of a number of studies failed to support the hypothesis that larger organisational size can be linked to higher levels of intrapreneurship. Cognisance must also be taken of the fact that Schumpeter defined intrapreneurship around innovations alone. Kamine and Schwartz (1975) note that studies that failed to support the Schumpeterian hypothesis, measured innovative activity by some absolute index such as R\&D expenditure Jennings (1996: 2). It should be noted that this study used the ENTRESCALE in which innovativeness was also measured in terms of absolutes.

Vossen (1996) believes that the answer to higher intrapreneurship levels lie in the combination of the relative advantages of small and large organisations. His summary of the relative strengths of organisations is depicted in Table 6 below.

\section{Table 6: Relative advantages of small and large organisations}

\begin{tabular}{l|l}
\hline Small organisations & Large organisations \\
\hline Little bureaucracy & Formal management skills \\
\hline Rapid decision making & $\begin{array}{l}\text { Able to control complex } \\
\text { organisations }\end{array}$ \\
\hline Risk taking & $\begin{array}{l}\text { Can spread risk over products } \\
\text { or portfolios }\end{array}$ \\
\hline $\begin{array}{l}\text { Motivated and committed } \\
\text { management }\end{array}$ & $\begin{array}{l}\text { Functional expertise in staff } \\
\text { functionaries }\end{array}$ \\
\hline Motivated labour and effective & More specialised labour \\
\hline $\begin{array}{l}\text { Rapid che and resources to establish } \\
\text { communication, shorter chains } \\
\text { comprehensive external science } \\
\text { and technology networks }\end{array}$ \\
\hline $\begin{array}{l}\text { Fast reaction to changing } \\
\text { market requirements }\end{array}$ & $\begin{array}{l}\text { Comprehensive distribution and } \\
\text { servicing facilities }\end{array}$ \\
\hline $\begin{array}{l}\text { Can dominate narrow market } \\
\text { niches }\end{array}$ & $\begin{array}{l}\text { High power with existing } \\
\text { products }\end{array}$ \\
\hline R\&D efficiency & $\begin{array}{l}\text { Economies of scale and scope } \\
\text { in R\&D }\end{array}$ \\
\hline $\begin{array}{l}\text { Can support large R\&D } \\
\text { laboratories }\end{array}$ \\
\hline $\begin{array}{l}\text { Access to external capital } \\
\text { innovation through tacitness of } \\
\text { knowledge }\end{array}$ & $\begin{array}{l}\text { Better able to fund } \\
\text { diversification, synergy }\end{array}$ \\
\hline Capacity for customisation \\
$\begin{array}{l}\text { Able to obtain learning curve } \\
\text { economies through investment } \\
\text { adapting routines and strategy }\end{array}$ \\
\hline $\begin{array}{l}\text { Capacity for absorption of new } \\
\text { knowledge / technology }\end{array}$ \\
Able to erect entry barriers \\
\hline fast learning and
\end{tabular}

Source: Vossen, 1996: 5. 
The opposed views on the relationship between organisational size and intrapreneurship, as well as the finding of this study that age does not necessarily influence intrapreneurship, can possibly be understood through Baron's (1999) viewpoint that entrepreneurship is a behavioural trait that can be acquired through training and implementation, unlike intelligence. Interpreted for corporate environments, its counterpart intrapreneurship can thus be implemented in organisations of any size.

\section{Beta}

The perceived risk profile calculated by the volatility measure, the Beta coefficient $(\beta)$ correlates positively with three of the four key factors. Proactiveness and Management's correlations with the Beta are significant. Organisations that can thus be described as more intrapreneurial could have higher Beta coefficients. It stands to reason that an organisation, which for example has a higher risk-taking propensity, will be seen as more 'risky' relative to the market in which it operates, and thus the resultant correlation.

This finding confirms the issue of risk aversion. The literature study belaboured the fact that a number of misconceptions exist about entrepreneurs (and as such also about intrapreneurs). The most common is that entrepreneurs are seen as risk-takers or exhibiters of 'risky' behaviour. This view can be related to a similar view of organisations. Organisations that are bold, do take risks (through venturing), and that are aggressive in their competitive posture can be perceived as risky and this will be displayed through the volatility of their shares. However, the literature established that these elements constitute in part intrapreneurship and that intrapreneurship is necessary as a strategy to survive and excel in business (Struwig, 1991). The need to re-educate the market about entrepreneurs, and specifically the fact that entrepreneurs manage risk rather than just take risks, could also be proposed in terms of the assessment of the perceived risk of shares. Such a re-education process could result in the decreased volatility of a specific company's share because the expected future cash flows, which are reflected in the share prices, are seen as stable. Of specific importance could be the highlighting of the so-called 'parameterised intrapreneurship' in which the need for control (inclusive of risk management) is balanced with intrapreneurial freedom. Similarly understanding and communication of internal intrapreneurship systems, which contain and manage risk, can help to improve understanding intrapreneurial organisations. Examples of the elements of internal intrapreneurial systems that are highlighted in the study are systems for Intracapital and for the management of innovations and creativity.

The finding of this study that there is significant correlation between the Betas and the intrapreneurship key factors, contributes to the understanding of systemic risk.

\section{References}

Adizes, I. 1988. Corporate lifecycles: How and why corporations grow and die and what to do about it. New Jersey: Prentice Hall, 361p.

Aldrich, H \& Auster, E.R. 1986. 'Even dwarfs started small: Liabilities of age and size and their strategic implications', Research in Organisational Behavior, 8: 165-198.

Amabile, T.M., Conti, R., Coon, H., Lazenby, J. \& Herron, M. 1996. 'Assessing the work environment for creativity', Academy of Management Journal, 39(5): 1180-1197.

Antoncic, B. \& Hisrich, R.D. 2001. 'Intrapreneurship: Construct refinement and cross-cultural validation', Journal of Business Venturing, 16: 495-527.

Baron, R.A. 1999. Professor of Management, Rennselaer Politechnic Institute, Vancouver: Personal interview, 8 May.

Birkinshaw, J. 1999. 'The determinants and consequences of subsidiary initiative in multinational corporations', Entrepreneurship Theory \& Practice, 24(1): 9-36.

Bloodgood, J.M. Sapienza, H.J. \& Almeida, J.G. 1995. The internationalisation of new high potential ventures: Antecedents and outcomes. Frontiers of Entrepreneurship Research. [online] URL: http://www.babson.edu. Accessed: 20 August 2002.

Bureau for Financial Analysis. 2002. [online] URL: http://www mcgbfa.com. Accessed: 1 February 2002.

Brazeal, D.V. 1996. 'Managing an entrepreneurial organisational environment: A discriminant analysis of organisational and individual differences between autonomous unit managers and department managers', Journal of Business Research, 35: 55-67.

Caspari, J. 1985. What's your E.Q. Milwaukee, WI: Northwestern Mutual Life Insurance Company.

Chandler, A.D. 1962. Strategy and structure: Chapter in the history of the American industrial complex. Cambridge: MA: MIT Press, 722p.

Covin, J.G. \& Slevin, D.P. 1989. 'Strategic planning of small firms in hostile and benign environments', Strategic Management Journal, 10: 75-87.

Dougherty, D. 1990. 'Understanding new markets for new products’, Strategic Management Journal, 11: 59-78.

Doz, Y \& Prahalad, C. 1981. 'Headquarters' influence and strategic control in MNCs', Sloan Management Review, 22(4): 5-13.

Ducan, W.J., Ginter, P.M., Rucks, A.C. \& Jacobs, T.D. 1988. 'Intrapreneurship and the reinvention of the corporation', Business Horizons, 31(3): 16-21. 
Engelhoff, W.G. 1984. 'Patterns of control in US, UK and European multinational corporations', Journal of International Business Studies, 15: 73-83.

Ettie, J.E. 1983. 'Organizational policy and innovation among processors to the food-processing sector', Academy of Management Journal, 26(26): 27-44.

Faul, N.H. 1986. 'A key factors approach to productivity improvement'. Unpublished $\mathrm{PhD}$ dissertation. Cape Town: University of Cape Town.

Fry, A. 1987. 'The post-it note: An intrapreneurial success', SAM Advanced Management Journal, Summer: 4-9.

Galbraith, J. 1982. 'The stages of growth', Journal of Business Strategy, 3(4): 70-79.

Gardiner, P. \& Whiting, P. 1997. 'Success factors in learning organisations: An empirical study', Industrial and Commercial Training, 4(2): 44-46.

Gartner, W.B. 1989. "Who is an entrepreneur?" is the wrong question', Entrepreneurship, Theory and Practice, Summer: 47-68.

Guth, W. \& Ginsberg, A. 1990. 'Guest editor's introduction: Corporate entrepreneurship', Strategic Management Journal, 11: 5-16.

Jones, G.R. \& Butler, J.E. 1992. 'Managing internal corporate entrepreneurship: An agency theory perspective', Journal of Management, 18: 733-749.

Jennings, D.F. 1996. 'Entrepreneurial activity and firm size: Re-examining Schumpeter's hypotheses'. [online] URL: http://www.sbaer.uca.edu/Research/1996/USASBE/96usa19 5.txt.Accessed: 11 September 2002.

Kamien, M.I. \& Schwartz, N.L. 1975. 'Market structure and innovation: A survey', Journal of Economic Literature, 13: $1-37$.

Khandwalla, P.N. 1977. The design of organisations. New York: Harcourt Brace Jovanovich Inc. 712p.

Knight, K.E. 1997. 'Cross-cultural reliability and validity of a scale to measure firm entrepreneurial orientation', Journal of Business Venturing, 12: 213-225.

Kurato, D.F., Hornsby, I.S., Naffziger, D.W. \& Montagno, R.V. 1993. 'Implement entrepreneurial thinking in established organisations', SAM Advanced Management Journal, Winter, 58(1): 28-39.

Mansfield, E. 1963. 'Size of firm, market structure, and innovation', Journal of Political Economy, 71(6): 556-572.

Miller, D. \& Friesen, P.H. 1983. 'Innovation in conservative and entrepreneurial firms: Two models of strategic momentum', Strategic Management Journal, 3: 125 .
Mintzberg, H. \& Waters, J. 1982. 'Tracking strategy in an entrepreneurial firm', Academy of Management Journal, 25: 465-499.

Mohamed, M.Z. \& Rickards, T. 1996. 'Assessing and comparing the innovativeness and creative climate of firms', Scandinavian Journal of Management, 12(2): 109121.

Morris, M.H. \& Kurato, D.F. 2001. 'Towards integration: Understanding entrepreneurship through frameworks', The International Journal of Entrepreneurship and Innovation, February: 35-49.

Morris, M.H. \& Sexton, D.L. 1996. 'The concept of entrepreneurial intensity: Implications for company performance', Journal of Business Research, 36: 5-13.

Nunnally, J.C. 1978. Psychometric theory. New York: McGraw-Hill, 701p.

Pallant, J. 2001. SPSS Survival manual. Buckingham: Open University Press, 273p.

Pinchot III, G. 1989. 'Fostering intrapreneurship in organisations', Developing Human Resources: 242-252,

Profile. 2000. JSE Handbook. Johannesburg: Profile Media, 464p.

Pryor, A.K. \& Shays, E.M. 1993. 'Growing the business with intrapreneurs', Business Quarterly, Spring: 43-45.

Robinson, P.B., Stimpson, D.V., Huefner, J.C. \& Hunt, H.K. 1991. 'An attitude approach to the prediction of entrepreneurship', Entrepreneurship Theory and Practice, Summer: 13-31.

Romanelli, E. 1987. 'New venture strategies in the microcomputer industry', California Management Review, 30(1): 160-175.

Rubin, H.J. 1983. Applied social research. Ohio: Merrill Publishing, 502p.

Sathe, V. 1989. 'Fostering entrepreneurship in the large, diversified firm', Organisational Dynamics, 18(1): 20-32.

Scherer, F.M. 1965. 'Corporate inventive output, profits, and growth', Journal of Political Economy, 73: 290-297.

Smit, G.J. 1991. Psigometrika: Aspekte van toetsgebruik. Pretoria: HAUM. 449p.

Stevenson, H.H. \& Jarillo, J.C. 1990. 'A paradigm of entrepreneurship: Entrepreneurial management', Strategic Management Journal, 11: 17-27.

Stopford, J.M. \& Baden-Fuller, C.W.F., 1994. 'Creating corporate entrepreneurship', Strategic Management Journal, 15: 511-536. 
Nooteboom, B. 1994. 'Innovation and diffusion in small firms: Theory and evidence', Small Business Economics, 6: 327-347.

Struwig, F.W. 1991. 'Intrapreneurship: A strategy for managing change and innovation'. Unpublished DPhil dissertation. Port Elizabeth: Vista University.

Tabachnick, B.G. \& Fidell, L.S. 1996. Using multivariate statistics. 3rd ed. New York: Harper Collins, 653p.

Tushman, M.L. \& Nelson, R.R. 1990. 'Introduction: Technology, organisations and innovation', Administrative Science Quarterly, 35: 1-8.

Vossen. 1996. Combining small and large firm advantages in innovation: Theory and examples. [online] URL: http://www.ub rug nl/eldoc/som/b/98B21/98b21.pdf. Accessed: 20 August 2002.

Zahra, S.A. 1991. 'Predictors and financial outcomes of corporate entrepreneurship: An exploratory study', Journal of Business Venturing, 6(4): 259-285.

Zahra, S.A. 1993a. 'New product innovation in established companies: Associations with industry and strategy variables', Entrepreneurship Theory and Practice, Winter: 47-69.

Zahra, S.A. 1993b. 'Environment, corporate entrepreneurship and financial performance: A taxonomic approach', Journal of Business Venturing, 8(4): 319-340.

Zahra, S.A., Dharwadkar, R. \& George, G. 2000. Entrepreneurship in multinational subsidiaries: The effects of corporate and local environmental contexts. [online] URL: http://www.ciber.gatech.edu/workingpaper/99_0027.pdf. Accessed: 13 September 2002. 


\section{APPENDIX A \\ THE FINAL QUESTIONNAIRE \\ EXECUTIVE QUESTIONNAIRE}

The objective of this survey is to determine your organisation's views on corporate entrepreneurship.

The study is anonymous. Confidentiality is guaranteed.

The questionnaire consists of statements about your organisation. After you have read each statement, decide on the degree to which the statement accurately describes your organisation's views or opinions. Use the following scale:

1. Completely disagree

2. Mostly disagree

3. Slightly disagree

4. Undecided

5. Slightly agree

6. Mostly agree

7. Completely agree

Example:

Insert you choice in the column to the left of the scale as depicted below

How many new lines of products or services has your organisation marketed since 1997?

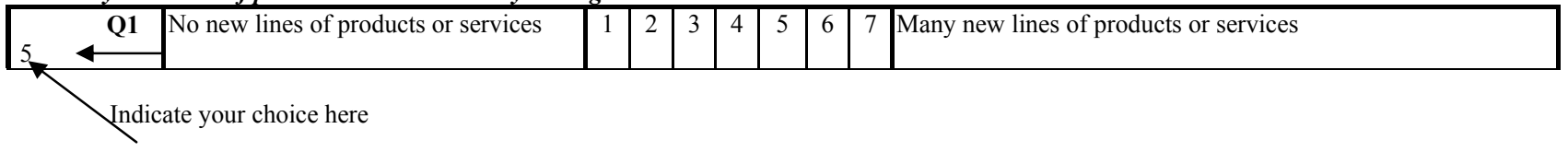

When you have completed all the items, please save, and attach the questionnaire to an

e-mail to the following address: mailto:Cgoosen@medic.up.ac.za cgoosen@medic.up.ac.za or post to P.O. Box 75932

Lynnwood Ridge 0040 or fax to 012-3212236

ORGANISATION NAME:

How many new lines of products or services has your organisation marketed since 1997?

\begin{tabular}{|l|l|l|l|l|l|l|l|l|l|l|l|}
\hline & $\mathbf{Q 1}$ & $\begin{array}{l}\text { No new lines of products or } \\
\text { services }\end{array}$ & 1 & 2 & 3 & 4 & 5 & 6 & 7 & Many new lines of products or services \\
\hline
\end{tabular}

Were changes to lines of products or services minor or dramatic?

\begin{tabular}{|l|l|l|l|l|l|l|l|l|l|l|}
\hline $\mathbf{Q 2}$ & $\begin{array}{l}\text { Changes in product or service } \\
\text { lines mostly of a minor nature }\end{array}$ & 1 & 2 & 3 & 4 & 5 & 6 & 7 & $\begin{array}{l}\text { Changes in product or service lines have usually been quite } \\
\text { dramatic }\end{array}$ \\
\hline
\end{tabular}

In general, top management in my organisation favour ...

\begin{tabular}{|l|l|l|l|l|l|l|l|l|l|l|}
\hline Q3 & $\begin{array}{l}\text { A strong emphasis on the } \\
\text { marketing of tried and true } \\
\text { products or services }\end{array}$ & 1 & 2 & 3 & 4 & 5 & 6 & 7 & $\begin{array}{l}\text { A strong emphasis on R\&D, technological leadership, and } \\
\text { innovations }\end{array}$ \\
\hline
\end{tabular}

In dealing with competitors, my organisation ...

\begin{tabular}{|l|l|l|l|l|l|l|l|l|l|l|}
\hline $\mathbf{Q 4}$ & $\begin{array}{l}\text { Is seldom the first business to } \\
\text { introduce new products or } \\
\text { services, administrative } \\
\text { techniques, operating } \\
\text { technologies etc. }\end{array}$ & 1 & 2 & 3 & 4 & 5 & 6 & 7 & $\begin{array}{l}\text { Is very often the first business to introduce new products or } \\
\text { services, administrative techniques, operating technologies etc. }\end{array}$ \\
\hline $\mathbf{Q 5}$ & $\begin{array}{l}\text { Typically avoid competitive } \\
\text { clashes, preferring the "live-and- } \\
\text { let-live" posture }\end{array}$ & 1 & 2 & 3 & 4 & 5 & 6 & 7 & Typically adopts a very strong 'undo-the-competitors' posture \\
\hline
\end{tabular}

In general, top management at my organisation ...

\begin{tabular}{|l|l|l|l|l|l|l|l|l|l|l|}
\hline Q6 & $\begin{array}{l}\text { Have a strong tendency to } \\
\text { select low-risk projects (with } \\
\text { normal and certain rates of } \\
\text { return) }\end{array}$ & 1 & 2 & 3 & 4 & 5 & 6 & 7 & $\begin{array}{l}\text { Have a strong tendency towards high risk projects (with high } \\
\text { rates of return) }\end{array}$ \\
\hline
\end{tabular}




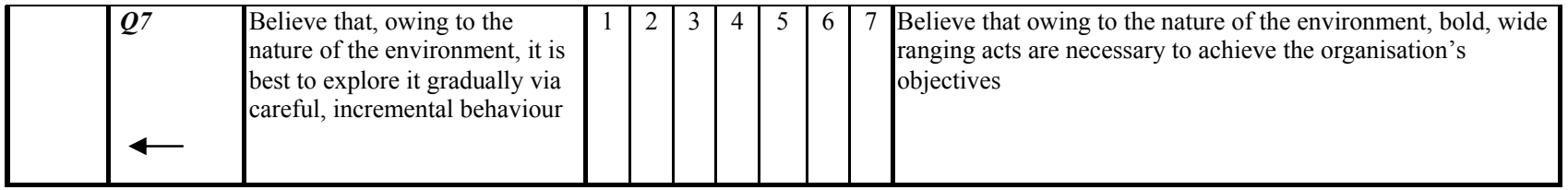

When confronted with decision-making situations involving uncertainty, my organisation...

\begin{tabular}{|l|l|l|l|l|l|l|l|l|l|l|}
\hline Q8 & $\begin{array}{l}\text { Typically adopts a cautious } \\
\text { 'wait and see' posture in order } \\
\text { to minimize the probability of } \\
\text { costly decisions. }\end{array}$ & 1 & 2 & 3 & 4 & 5 & 6 & 7 & $\begin{array}{l}\text { Typically adopts a bold, aggressive posture in order to } \\
\text { maximize the probability of exploiting potential opportunities }\end{array}$ \\
\hline
\end{tabular}

In this organisation....

\begin{tabular}{|lllllllllll|}
\hline Q9 & Entrepreneurial activities are included in goal setting for staff. \\
& Completely disagree & 1 & 2 & 3 & 4 & 5 & 6 & 7 Completely agree \\
\hline
\end{tabular}

Q10 This organisation has systems that actively develop creativity and innovation.

$\begin{array}{lllllllll} & \text { Completely disagree } & 1 & 2 & 3 & 4 & 5 & 6 & 7 \text { Completely agree }\end{array}$

$\begin{array}{lllllllllll}\text { Q11 In this organisation innovation is rewarded. } & & & & & \\ & \text { Completely disagree } & 1 & 2 & 3 & 4 & 5 & 6 & 7 \text { Completely agree }\end{array}$

\begin{tabular}{|lllllllllll|}
\hline Q12 & This organisation allocates a specific portion of the budget for the development of new ideas/projects. \\
\hline
\end{tabular}

\begin{tabular}{|lllllllllll|}
\hline Q13 & Work teams/groups communicate well in this organisation. \\
\hline & Completely disagree & 1 & 2 & 3 & 4 & 5 & 6 & 7 Completely agree \\
\hline
\end{tabular}

\begin{tabular}{|lllllllllll|}
\hline Q14 & Management accepts suggestions from employees. & & \\
\hline & Completely disagree & 1 & 2 & 3 & 4 & 5 & 6 & 7 Completely agree \\
\hline
\end{tabular}

\begin{tabular}{|lllllllllll|}
\hline Q15 & There is freedom in this organisation to do one's own thing. \\
\hline & Completely disagree & 1 & 2 & 3 & 4 & 5 & 6 & 7 Completely agree \\
\hline
\end{tabular}

\begin{tabular}{|llllllllllll}
\hline Q16 & Employees are encouraged to solve problems creatively. \\
\hline & Completely disagree & 1 & 2 & 3 & 4 & 5 & 6 & 7 Completely agree \\
\hline
\end{tabular}

\begin{tabular}{|llllllllll|}
\hline Q17 & Management supports new projects and ideas. & & \\
\hline & Completely disagree & 1 & 2 & 3 & 4 & 5 & 6 & 7 Completely agree \\
\hline
\end{tabular}

\begin{tabular}{|llllllllll|}
\hline Q18 & In this organisation employees are empowered. & & \\
\hline & Completely disagree & 1 & 2 & 3 & 4 & 5 & 6 & 7 Completely agree \\
\hline
\end{tabular}

